\title{
末梢静脈カテーテル管理におけるイベント交換の費用最小化分析
}

\author{
武田 由美1,2) - 網中眞由美1) 坂木 晴世 2$) \cdot$ 福田 哲也 ${ }^{3}$ \\ 駒形 奈央 $\left.{ }^{2}\right) \cdot$ 藤田 烈 4$) \cdot$ 森 $\quad$ 那美子 ${ }^{1)} \cdot$ 西岡み(゙り ${ }^{1)}$
}

\section{Cost Minimization Analysis of Clinically-Indicated Replacement in Peripheral Venous Catheter Management}

\author{
Yumi TakedA ${ }^{1,2)}$, Mayumi AminakA ${ }^{1)}$, Haruyo SAKaki ${ }^{2)}$, Tetsuya FukudA ${ }^{3)}$, \\ Nao Komagata ${ }^{2)}$, Retsu Fujita ${ }^{4)}$, Namiko Mori ${ }^{1)}$ and Midori NishiokA ${ }^{1)}$ \\ ${ }^{1)}$ Graduate School of Nursing, National College of Nursing, Japan, \\ ${ }^{2)}$ Department of Nursing, ${ }^{3)}$ Department of Pharmacy, Nishisaitama-cyuo National Hospital, \\ 4) The University Tokyo Hospital, Clinical Research Support Center (CresCent)
}

（2015 年 7 月 14 日 受付 $\cdot 2015$ 年 11 月 9 日 受理)

要旨

米国疾病予防管理センター (CDC) ガイドラインは, 末梢静脈カテーテルを $72 \sim 96$ 時間ごとに刺 し替える方法(定期交換)を推奨しているが，近年の研究では，臨床的に刺し替えざるを得ないイべ ント(静脈炎等)が生じた場合だけ刺し替える方法(イベント交換)の安全性が示された. 本研究で は,「イベント交換」が導入された一施設でヒストリカルコントロールを用いた後ろ向き調査を行 い，イベント交換の安全性を確認したうえで費用効果を検証した.

末梢静脈カテーテル関連サーベイランス記録と診療録より，患者属性とイベント発生率を調査し た. 費用は, 輸液療法 1 回あたりの材料費, 人件費, 廃棄費を算出した. 導入後 1 か月を除く前 後 2 か月間のイベント (血流感染, 静脈炎, 血管外漏出, 閉塞)の発生率とカテーテル刺し替えに かかる費用を比較した．末梢静脈カテーテルを「定期交換」から「イベント交換」に変更してもイ ベント発生率に有意な上昇はなかった．費用最小化分析の結果, 「定期交換」を止め,「イベント交 換」を導入したことによる増分費用は，輸液療法 1 回あたり - 268 円であった.

Key words : 末梢静脈カテーテル, 費用最小化分析, 静脈炎, 血流感染, イベント交換

はじめに

末梢静脈カテーテル輸液療法は, 急性期病床だけでな く, 慢性期病床, 療養病床, 在宅においても日常的に行 われている. 末梢静脈カテーテルの管理については, 米 国疾病予防管理センター(Centers for Disease Control and Prevention: CDC)が血流感染や静脈炎を防止するた めに 72〜96 時間ごとに刺し替える「定期交換」を推奖 してきた ${ }^{1,2)}$. 米国輸液看護師協会 (Infusion Nursing Society; INS)のガイドラインにおいても ${ }^{3)}$, 血流感染や

1)国立看護大学校研究課程部, 国立病院機構西埼玉中央病院 2) 看護部, 3) 薬剂部, 4) 東京大学医学部附属病院臨床支援研究セ ンター
静脈炎の発生予防のために $72 \sim 96$ 時間ごとに末梢静脈 カテーテルを刺し替えるよう推奖している.

他方, 2013 年の Webster らのコクランレビューで は, 静脈炎等の徵候が現れ, 臨床的に刺し替えが必要々 なった場合のみ末梢静脈カテーテルを刺し替える方法 (以下「イベント交換」)の安全性が示された ${ }^{4)}$ 。このレ ビューでは，メタアナリシスによって，「定期交換」と 「イベント交換」とでは, 血流感染, 静脈炎等の合併症 発生率が同等であることが明らかにされた4).

A 病院では, このWebster らのレビューを院内感染 対策委員会で検討し，2014 年 1 月 1 日に末梢静脈力 テーテルの「定期交換」を止め，「イベント交換」を導 入した. 海外の研究では,「定期交換」から「イベント 
交換」に変更することで患者の苦痛が軽減することが明 らかになっている4,5). また, 刺し替えるにかかる材料 費や，医療者が刺し替えに費やす時間が減少することに よる費用削減効果も示唆されている ${ }^{5 \sim 7)}$. しかしこれら の検討では，廃棄費は費用に算入されていない。また， 診療報酬制度が異なる日本における経済性についての検 証はされていない。

そこで本研究では, 先述の $\mathrm{A}$ 病院で導入された「イ ベント交換」の安全性を確認したうえで費用効果を検証 することを目的とした。

\section{対象と方法}

\section{1. 対 象}

ヒストリカルコントロールを用いた後ろ向き調査によ る費用最小化分析を行った. 300 床規模の第二次救急医 療指定施設である $\mathrm{A}$ 病院において末梢静脈カテーテル 使用頻度が高い 2 つの内科外科混合病棟を対象病棟と した。

調査期間は， 2013 年 11 月 1 日 2014 年 3 月 31 日 とした。「定期交換」期間は 2013 年 11 月 1 日〜 12 月 31 日，「イベント交換」期間は 2014 年 2 月 1 日〜 3 月 31 日とした。なお， 2014 年 1 月 1 日〜 1 月 31 日の 1 か月間は移行期間として除外した（図 1).

対象の適格基準は, $\mathrm{A}$ 病院対象病棟に入院した 16 歳 以上の患者に行った調査期間中における初回の末梢静脈 カテーテル輸液療法とした. したがって, 調査対象にお ける患者の重複はない. 対象の除外基準は, 他の医療機 関または他の病棟での末梢静脈カテーテル挿入, 複数の 末梢静脈カテーテル扦入, 末梢静脈カテーテル以外の血 管デバイス扦入，「定期交換」期間における「イベント 交換」のみの実施, 「イベント交換」期間における「定 期交換」の実施とした。

なお，末梢静脈カテーテルは末梢静脈に挿入される $7.6 \mathrm{~cm}$ 未満のポリウレタン製カテーテルとし, 末梢静 脈扦入式中心静脈カテーテル (peripherally inserted central catheter: PICC)は除外した.

本研究では，末梢静脈カテーテルを抜去せざるをえな いイベントを血流感染 $4 \sim 7)$, 静脈炎 ${ }^{4 \sim 6,8 \sim 10)}$, 血管外漏

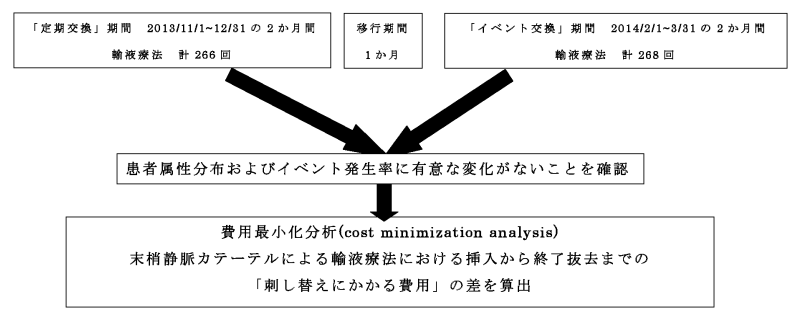

図 1 研究デザイン
出 ${ }^{4 \sim 6,8,11)}$, 閉塞とした ${ }^{4 \sim 6)}$.

\section{2.「定期交換」と「イベント交換」}

「定期交換」期間中は, 治療終了までに閉塞の徵候, 血管外漏出の徵候, 発赤·腫脹 · 熱感 · 疼痛等の静脈炎 の徵候がなくても，72９6 時間ごとにカテーテルを刺 し替えていた. カテーテルの刺し替えは，輸液ボトルを 更新するタイミングで行っていた。 また，閉塞の徵候， 血管外漏出の徵候, 静脈炎の徵候 (発赤 · 腫脹 · 熱感 · 疼痛等)があった場合にもカテーテルを刺し替えていた。

「イベント交換」期間中は, 閉塞の徵候, 血管外漏出 の徵候, 静脈炎の徵候があった場合のみカテーテルを刺 し替えていた。

いずれの刺し替えも，新しい輸液ラインを使用して再 挿入し, 輸液療法を続行していた(図 2).

3. $\mathrm{A}$ 病院における末梢静脈カテーテル関連サーベイ ランス

$\mathrm{A}$ 病院では, 感染症看護専門看護師と感染管理認定 看護師が末梢静脈カテーテル関連サーベイランスを「定 期交換」の時期から行っていた.

サーベイランス指標としてのイベント（血流感染，静 脈炎, 血管外漏出, 閉塞)の判定基準は以下の通りであ る. 血流感染は, $\mathrm{CDC} の 「$ 血液培養検査で微生物が確 認された血流感染 (laboratory confirmed bloodstream infection: LCBI)」と「臨床的敗血症 (clinical sepsis: CSEP)」の基準を用いていた ${ }^{12)}$ 。静脈炎は，「静脈炎ス コア visual infusion phlebitis score: VIP Score」を用い, 静脈炎スコアが 1 点以上を基準としていた ${ }^{13)}$. 血管外 漏出は, 米国輸液看護師協会 (INS) による血管外漏出入 ケール infiltration scaleを用い，1点以上を基準として いた ${ }^{13)}$. 閉塞は，留置針が血管壁にあたって一時的に 滴下しない状態は除き，輸液ルートを開放しても輸液が 自然滴下しない状態としていた。

イベント (血流感染, 静脈炎, 血管外漏出, 閉塞)の観 察は, 訓練を受けた病棟看護師がカテーテル挿入直後か

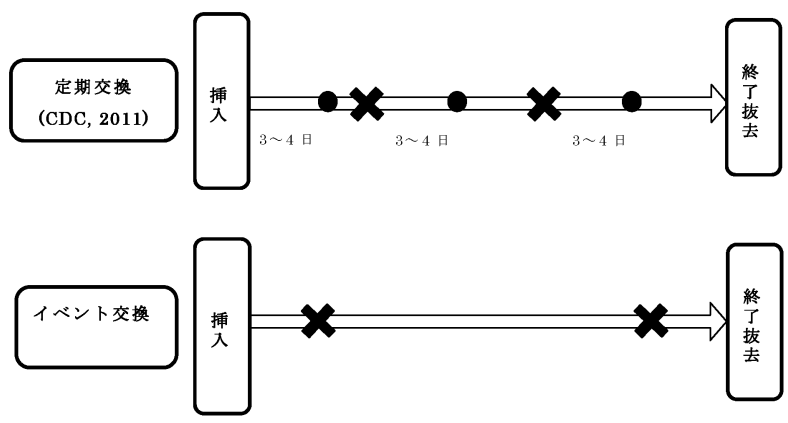

図 2 「定期交換」と「イベント交換」の例 72 96 時間(3〜4 日)ごとの刺し替え(定期交換) X 臨床的に刺し替えざるを得ないイベント（血流感染， 静脈炎, 血管外漏出, 閉塞) が発生したことによる刺 し替え(イベント交換) 
ら行い, 感染症看護専門看護師と感染管理認定看護師が 基準を用いて判定していた. なお, 静脈炎や血管外漏出 等複数のイベントが同時に生じた場合は，すべてカウン トしていた１輸液療法ごとのサーベィランス記録は集 計され, 結果が病棟の感染管理リンクナースと共有され ていた.

\section{4. 費用最小化分析}

費用効果分析には, 費用最小化分析を用いた。費用最 小化分析とは，新規技術と比較対照のアウトカムを同等 とした上で費用のみを検討する手法である14). カテー テル挿入抢よび抜去にかかる費用, 薬剤費, 光熱費, 固 定資産税等は両期間で不変であるため，相殺される．そ のため，両期間で異なった費用のみ比較した（図3). 先 行研究に抢いて「イベント交換」の安全性が示されてい るため, 今回の調査でもイベント発生率が有意に増えな いことを予測して，費用最小化分析を行った．したがっ て, 次項で述べる費用項目は, 輸液療法中の刺し替えに かかる材料費, 人件費, 廃棄費とした.

\section{5. 調査項目}

\section{1）患者属性項目}

患者属性項目は, 先行研究で末梢静脈カテーテルによ るイベント (血流感染, 静脈炎, 血管外漏出, 閉塞) との 関連が示唆されている年齢13,15,16), 性別9,10,16 18), 糖尿 病7,9,11), 悪性腫瘍 ${ }^{10,11)}$, 循環器疾患 ${ }^{11,19)}$, 免疫疾 患 7,10$)$, ステロイド・免疫抑制剂使用 7,10$)$, 認知症の有 無 ${ }^{11)}$ の 8 項目とし，診療録より収集した。

\section{2）刺し替え状況に関する項目}

血流感染, 静脈炎, 血管外漏出, 閉塞の発生の有無, カテーテルの挿入日時, 抜去日時, 刺し替え日時, 刺し 替えのタイミングでのシャワー浴や外出の有無をサーベ イランス記録より収集した。

\section{3）費用項目 \\ （1）材料費}

材料費は, A 病院で使用している手袋, アルコール 綿, 血管内留置針, 輸液ライン, 三方活栓, 延長チュー ブ, フィルムドレッシング材, サージカルテープ $(5 \mathrm{~cm}$ $\times 7 \mathrm{~cm})$ の購入価格とした．購入価格は定価ではなく， $\mathrm{A}$ 病院周辺の複数施設における購入価格を調査し, 平 均値を用いた。

\section{（2）人件費}

人件費は, 刺し替え所要時間に看護師時給を乗じて算 出した. 看護師時給は, $\mathrm{A}$ 病院に拈ける看護師常勤換 算式を用いて算出した職員の時給 (保険料, 福利厚生 費，退職積立金等を除く)とした。刺し替え所要時間 は，「末梢静脈カテーテルの刺し替え」にかかる時間と 「点滴準備室と病室間の移動」にかかる時間とした．「末 梢静脈カテーテルの刺し替え」にかかる時間は, 感染管 理認定看護師 3 名が, 次に述べる 3 つの臨床場面を再 現した患者への声かけを含む台本に沿って，A病院で 使用している材料を用いて各 3 回実演して測定した時 間の平均值を採用した． 3 つの臨床場面は，“定期の刺 し替え”, “カテーテル抜去と再挿入”, “イベント徵候に よる刺し替え”とした(表 1).「点滴準備室と病室間の 移動」にかかる時間は，感染管理認定看護師 1 名と調 查病棟の感染制御チームメンバー 1 名が, 点滴準備室 と全病室間を 2 回歩行しストップウオッチを用いて実 測した平均值を採用した.

\section{(3) 廃棄費}

廃棄費は, $\mathrm{A}$ 病院に打ける可燃ゴミ, 不燃ゴミ, 感 染性廃棄物の重量あたりの処理費用にそれぞれの重量を 乗じて算出した. 重量は,「末梢静脈カテーテルの刺し 替え」にかかる時間測定のための実演で排出した廃棄物

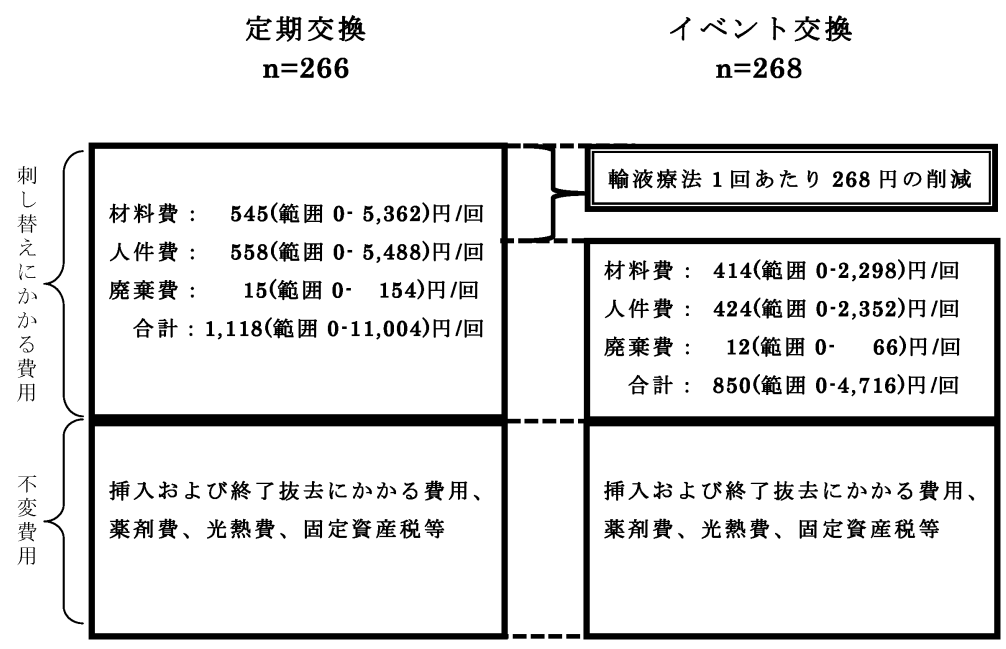

図 3 費用最小化分析結果 


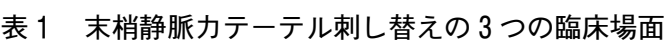

\begin{tabular}{|c|c|c|}
\hline 定期の刺し替え & カテーテル抜去と再挿入 & イベント徵候による刺し替え \\
\hline 1. 新しい輸液セット作成 & 1. カテーテル抜去 & 1. 徵候発見 \\
\hline 2. 移動 (準備室～病室) & 2. 移動(病室～準備室) & 2. カテーテル抜去 \\
\hline 3. カテーテル抜去 & 3. 片付け & 3. 移動 (病室～準備室) \\
\hline 4. カテーテル再挿入 & 【シャワー浴や外出等】 & 4. 片付け \\
\hline 5. 移動 (病室～準備室) & 4. 新しい輸液セット作成 & 5. 新しい輸液セット作成 \\
\hline \multirow[t]{4}{*}{ 6. 片付け } & 5. 移動 (準備室～病室) & 6. 移動 (準備室～病室) \\
\hline & 6. カテーテル再指入 & 7. カテーテル再挿入 \\
\hline & 7. 移動(病室～準備室) & 8. 移動 (病室～準備室) \\
\hline & 8. 片付け & 9. 片付け \\
\hline
\end{tabular}

\footnotetext{
a.「定期交換」期間は，“定期の刺し替え”，“イベント徵候による刺し替え”を実施

b.「イベント交換」期間は, “イベント徵候による刺し替え”を実施

c. 両期間とも, 患者の希望によりシャワー浴や外出等のタイミングで“カテーテル抜去と再挿入”を実施
}

を分別し精密重量計(島津製作所製 電子天びん)を用い て計測した.

\section{6. 分析方法}

「定期交換」期間と「イベント交換」期間の患者属性 分布とイベント発生率に統計学的に有意な差がないこと を確認した。「定期交換」から「イベント交換」へ変更 したことによる輸液療法 1 回あたりの増分費用を算出 した.

イベント発生率は，次の式を用いて算出した.

イベント発生率 (件/1,000 末梢静脈カテーテル日)

$$
=\frac{\text { イベント発生件数 }}{\text { 末梢静脈カテーテル留置日数合計 }} \times 1,000
$$

増分費用は，次の式を用いて算出した。

輸液療法 1 回あたりの増分費用(円/輸液療法)

$$
=\begin{gathered}
\text { 「イベント交換」期間における 「定期交換」期間におけ掖療法 } 1 \text { 回あたり } \\
\text { 材料費, 人件費, 廃棄費 }
\end{gathered}
$$

なお両期間の材料費，人件費，廃棄費は，対象輸液療 法 1 回ごとに実際の刺し替え状況と回数に応じて算出 した。

統計学的検定は，変数の種類に応じて，フィッシャー の直接確率検定またはウィルコクソンの順位和検定を行 った．有意水準は $\alpha=0.05$ とした．分析にはSAS system Ver.9.4を用いた。

\section{7. 倫理的配慮}

調査開始にあたり，調査施設倫理委員会の承認を得た （倫理委員会承認番号 26-小 02).

\section{結果}

期間中の輸液療法は，「定期交換」期間に「イベント 交換」をした 15 回と「イベント交換」期間に複数の末

\begin{tabular}{|c|c|c|c|}
\hline 項 & $\begin{array}{l}\text { 定期交換 } \\
(n=266)\end{array}$ & $\begin{array}{c}\text { イベント交換 } \\
(\mathrm{n}=268)\end{array}$ & $\mathrm{p}$ 值 ${ }^{*}$ \\
\hline 年齢(歳)* & $72(16-98)$ & $73(25-95)$ & 0.400 \\
\hline 性別 (男性)† & 158(59) & $157(59)$ & 0.861 \\
\hline 糖尿病 ${ }^{\dagger}$ & $59(22)$ & $50(19)$ & 0.334 \\
\hline 悪性腫瘍 & $70(26)$ & $74(28)$ & 0.770 \\
\hline 循環器疾患 ${ }^{\dagger}$ & $160(60)$ & $157(59)$ & 0.725 \\
\hline 免疫疾患 ${ }^{\dagger}$ & $8(3)$ & $14(5)$ & 0.276 \\
\hline $\begin{array}{l}\text { 副婜皮質ホルモン製剤, } \\
\text { 免疫抑制の使用 }\end{array}$ & $10(4)$ & $12(5)$ & 0.828 \\
\hline 認知症 ${ }^{\dagger}$ & 28(11) & $17(6)$ & 0.088 \\
\hline
\end{tabular}
梢静脈力テーテル扦入があった 5 回を除外し，「定期交 換」が 266 回，「イベント交換」が 268 回であった。以
表 2 患者属性分布の比較結果

* 数値は中央値, ( )内は範囲

† 数値は件数，（）内は\%

‡ウィルコクソンの順位和検定またはフィッシャーの直接確 率検定

下結果を，両期間の患者属性分布およびイベント発生 率，費用最小化分析結果の順に述べる.

\section{1. 両期間の患者属性分布およびイベント発生率}

患者属性 8 項目の分布に両期間で統計学的に有意な 違いは認められなかった(表 2).

血流感染は，両期間ともに発生がなかった．静脈炎発 生率は「定期交換」期間が 24.5 件/1,000 末梢静脈カテー テル日，「イベント交換」期間が 28.3 件/1,000 末梢静 脈カテーテル日であった $(\mathrm{p}=0.458)$. 血管外漏出や閉塞 の発生率も, 両期間で統計学的に有意な差は認められな かった (表 3)。輸液療法期間は，「定期交換」期間が中 央值 4(範囲 1-41) 日，「イベント交換」期間が中央值 4 （範囲 1-50）日であった。刺し替え回数は，「定期交換」 期間が中央值 1 (範囲 0-14) 回，「イベント交換」期間が 中央值 0 (範囲 0-6) 回であった $(\mathrm{p}=0.012)$.

\section{2. 費用最小化分析結果}

患者属性分布，イベント発生率において，両期間で統 計学的な有意差が認められなかったため, 費用最小化分 析を行った。A 病院では，末梢静脈カテーテルによる 
表 3 イベント発生率

\begin{tabular}{|c|c|c|c|}
\hline \multirow{2}{*}{ イベント } & \multicolumn{2}{|c|}{ 発生率(件/1,000 末梢静脈力テーテル日)* } & \multirow{2}{*}{ - $\mathrm{p}$ 值 ${ }^{\dagger}$} \\
\hline & 定期交換 & イベント交換 & \\
\hline 血流感染a & - & - & - \\
\hline 静脈炎 ${ }^{b}$ & 24.5 & 28.3 & 0.458 \\
\hline 血管外漏出 ${ }^{c}$ & 20.5 & 18.7 & 0.688 \\
\hline 閉塞d & 9.5 & 6.7 & 0.325 \\
\hline
\end{tabular}

* 発生率 $=$ イベント発生件数 $/$ 末梢静脈カテーテル留置日数 合計 $\times 1000$

†フィッシャーの直接確率検定

a. Centers for Disease Control and Prevention: CDC の「血 液培養検査で微生物が確認された血流感染 (laboratory confirmed blood stream infection: LCBI) 」と「臨床的敗 血症 (clinical sepsis: CSEP)」17) 血流感染は両期間ともに発生なし

b.「静脈炎スコア visual infusion phlebitis score: VIP Score」 1 点以上 ${ }^{18)}$

C. 輸液看護師協会による血管外漏出スケール infiltration Scale 1 点以上 ${ }^{18)}$

d. 輸液ルートを開放しても輸液が自然滴下しない状態 (留 置針が血管壁にあたって一時的に滴下しない状態は除外)

輸液療法 1 回あたりの刺し替えにかかる費用は，「定期 交換」期間では中央值 1,118(範囲 0-11,004) 円，「イベ ント交換」期間では中央值 850(範囲 0-4,716) 円であっ た.「定期交換」から「イベント交換」へ変更したこと による増分費用は，輸液療法 1 回あたり - 268 円であっ た(図 3).

\section{考察}

末梢静脈カテーテルを 72 96 時間ごとに刺し替える 「定期交換」は，2002 年 CDC ガイドラインで推奨され た1).「イベント交換」は， 2011 年のガイドライン改訂 時に検討されたが，静脈炎の発生リスクに関するエビデ ンスが不充分であるとして，採用されなかった。しかし その後の研究で,「定期交換」と「イベント交換」のイ ベント発生率は同等であることが示された4,5). 本研究 の結果でも, イベント発生率は, 両期間で統計学的に有 意な差は認められなかった.「イベント交換」期間の静 脈炎発生率は 28.3 件/1,000 末梢静脈カテーテル日であ り, 2013 年のコクランレビューの 13.9 件/1,000 末梢静 脈カテーテル日より高かった. 本研究における「イベン 卜交換」期間の静脈炎発生率が高值であった理由として 判定基準の違いによる可能性が考えられる. コクランレ ビューで用いられた 5 件の研究では静脈炎スコア 2 点 (挿入部付近の疼痛, 発赤, 腫脹のいずれか 2 つが観察 される) 以上で静脈炎と判定していた。 しかし本研究で は, 静脈炎スコア 1 点(挿入部付近の軽度の疼痛もしく は発赤のいずれか 1 つが観察される)であっても静脈炎 に含めた. 静脈炎スコア 2 点以上に基準を揃えて比較 すると, 本研究の静脈炎発生率は 9.6 件/1,000 末梢静
脈カテーテル日であり，先行研究に比べ高くなかった．

「定期交換」から「イベント交換」に变更することで, 刺し替えにかかる材料費, 人件費, 廃棄費ともに減少し た. 海外における先行研究では, 廃棄費の検討がされて はいないものの，刺し替えるための材料費や，医療者が 刺し替えに費やす時間が減少することによる費用削減効 果が示唆されており5 7), 今回の調査でも同様の結果を 得ることができた.

Rickard らは「イベント交換への変更は，コストを削 減し患者の不必要な痛みをなくす。」と述べている5). 刺し替えの回数が減少することにより, 患者の苦痛を回 避し，患者の満足度が向上すると考えられる．本研究結 果は, 末梢静脈カテーテルを挿入した後は, 患者の訴え があるまで刺し替えなくてもよいということではない. 静脈炎等の発見が遅れると血流感染の発生リスクが高ま る. 末梢静脈カテーテル関連血流感染は重大な合併症を 伴う症例が存在することが報告されている20). したが って「イベント交換」では，「定期交換」よりも一層綿 密な静脈炎徵候の観察が求められる. 末梢静脈カテーテ ル管理は，挿入から抜去までのすべての過程に沶いて看 護師が関わるため, 看護師 1 人 1 人の高い知識と技術 が要求される。海外では, 輸液管理を専門に担う intervenous team (IV チーム)が末梢静脈カテーテル管理を 行うことで, 血管外漏出, 静脈炎, 血流感染のリスクを 減少させるとの報告がある21)。A 病院では, 感染症看 護専門看護師, 感染管理認定看護師, 感染制御認定薬剤 師, 認定インフェクションコントロールドクター, リン クナースがチームで感染管理活動をしていた．感染症看 護専門看護師と感染管理認定看護師は，末梢静脈カテー テル関連サーベィランスを行い, 自身の観察結果やアセ スメントを診療録に記載し, 病棟看護師と情報共有して いた。 また，イベントの早期発見に繋がる観察力を育て るための訓練やカンファレンスを定期的に行っていた. このように A 病院では, 末梢静脈カテーテルが複数の 目で観察され，イベントを早期に発見し，遅滞なく抜去 することで，血流感染が防止されていたと考えられる. しかし, 末梢静脈カテーテル関連サーベイランスを行っ ていなかったり，イベント徵候を見逃すような観察状況 であったりすれば，却って血流感染の危険が高まること も否定できない.

中小規模病院や長期療養施設, 在宅の医療分野でも, 末梢静脈カテーテルが多く使用されている.「イベント 交換」は, 刺し替えの回数が減少することにより, 患者 の苦痛を回避し, 患者の満足度が向上し, 刺し替えにか かる費用の削減が期待できる，そのため今後は，中小規 模病院や長期療養施設, 在宅の分野にも感染症看護専門 看護師や感染管理認定看護師を配置して感染管理を推進 することが必要であると考えられる。 


\section{本研究の限界}

輸液療法における標準的な費用計算法はなく, 本研究 で算出された費用の金額は実験的に行われたデータに基 づくものである. また, 本研究は, 一施設で行われた調 査であり, 一般化するには複数施設において同様の結果 を検証する必要がある。

\section{結論}

末梢静脈カテーテルの「イベント交換」に関する費用 最小化分析の結果，「定期交換」から「イベント交換」 へ変更したことによる増分費用は, 輸液療法 1 回あた り-268 円であった。 イベント交換では, 静脈炎徵候を 遅滞なく発見するために感染症看護専門看護師や感染管 理認定看護師が末梢静脈カテーテル関連サーベイランス を行い, 訓練された看護師が綿密にイベント徵候を観察 する必要があると考える。

な打本研究は 2014 年度科学研究費助成事業(基盤研究 B) 「医療関連感染サーベイランスの活用による感染防止ケアの探 索(研究代表者 西岡みどり)」(JSPC 科研費 26293458)の一 部として実施し, 第 30 回日本環境感染学会総会・学術集会で 発表した。

謝 辞 : 本研究を行うにあたりご協力いただきました調査施設 のスタッフの皆様および実験にご協力いただきました感染管理 認定看護師の皆様に深謝いたします.

利益相反自己申告：申告すべきものなし.

文 献

1) O'Grady NP, Alexander M, Burns LA, Dellinger EP, Garland J, Heard, SO, et al.: CDC. Guidelines for the prevention of intravascular catheter-related infections 2011. Am J Infect Control 2011; 39 (4 Suppl 1): S1-34.

2) O'Grady NP, Alexander M, Dellinger EP, Gerberding JL, Heard, SO, Maki DG, et al.: CDC. Guidelines for the prevention of intravascular catheter-related infections. Infect Control Hosp Epidemiol 2002; 23(12): 759-69.

3) Alexander M, Mortlock N, Adams C, Phillips L, Siege $\mathrm{M}$, Sims A, et al.: Infusion nursing standards of practice. J Infus Nurs 2011; 34(1S): 1-110.

4) Webster J, Osborne S, Rickard CM, New K: Clinicallyindicated replacement versus routine replacement of peripheral venous catheters. Cochrane Database Syst Rev 2013; 30: 4.

5) Rickard CM, Webster J, Wallis MC, Marsh N, McGrail $\mathrm{MR}$, French V, et al.: Routine versus clinically indicated replacement of peripheral intravenous catheters: a randomised controlled equivalence trial. Lancet 2012; 22; 380 (9847): 1066-74.
6) Webster J, Lloyd S, Hopkins T, Osborne S, Yaxley M: Developing a Research base for Intravenous Peripheral cannula re-sites (DRIP trial). A randomised controlled trial of hospital in-patients. Int J Nurs Stud 2007; 44(5): 664-71.

7) Lavery I, Ingram P: Prevention of infection in peripheral intravenous devices. Nurs Stand 2006; 20 (49): 49-56; quiz 57.

8) Webster J, Clarke S, Paterson D, Hutton A, van Dyk S, Gale C, et al.: Routine care of peripheral intravenous catheters versus clinically indicated replacement: randomised controlled trial. BMJ 2008; 8; 337: a339.

9) Nassaji-Zavareh M, Ghorbani R: Peripheral intravenous catheter-related phlebitis and related risk factors. Singapore Med J 2007; 48(8): 733-6.

10) Tagalakis V, Kahn SR, Libman M, Blostein M: The epidemiology of peripheral vein infusion thrombophlebitis: a critical review. Am J Med 2002; $113(2)$ : 14651. Review.

11) Ingram P, Lavery I: Peripheral intravenous therapy: key risks and implications for practice. Nurs Stand 2005; 19 (46): 55-64; quiz 66. Review.

12) $\mathrm{CDC} / \mathrm{NHSN}$, 森兼啓太, 小林寛伊監訳 : 改訂第 4 版 サーベイランスのための CDC ガイドライン NHSN マ ニュアル(2007 年版)より(初版). メディカ出版, 大阪, 2008.

13) Dougherty L, Bravery K, Gabriel J, Kayley J, Malster $\mathrm{M}$, Scale $\mathrm{K}$, et al:: Standards for infusion therapy. The RCN IV Therapy Forum (Third ed.). The Royal College of Nursing, London, 2010. p. 1-94.

14）福田治久：医療関連感染領域における医療経済評価の 実施手法の概要. 環境感染誌 2014; 29(5): 324-32.

15) Dychter SS, Gold DA, Carson D, Haller M: Intravenous therapy: a review of complications and economic considerations of peripheral access. J Infus Nurs 2012; 35(2): 84-91.

16) Cicolini G, Bonghi AP, Di Labio L, Di Mascio R: Position of peripheral venous cannulae and the incidence of thrombophlebitis: an observational study. J Adv Nurs 2009; 65 (6): 1268-73.

17) Singth R , Bhandary S , Pun KD: Peripheral intravenous catheter related phlebitis and its contributing factors among adult population at KU Teaching Hospital. Kathmandu Univ Med J (KUMJ) 2008; 6(24): 443-7.

18) Hadaway L: Short peripheral intravenous catheters and infections. J Infus Nurs 2012; 35(4): 230-40.

19) Washington GT, Barrett R: Peripheral phlebitis: a point-prevalence study. J Infus Nurs 2012; 35 (4) : 2528.

20）佐藤昭裕, 中村 造, 福島慎二, 水野泰孝, 松本哲 哉: 末梢静脈カテーテルによる血流感染症の現状. 環 境感染誌 $2015 ; 30(1): 1-6$.

21) Gupta A, Mehta Y, Juneja R, Trehan N: The effect of cannula material on the incidence of peripheral venous thrombophlebitis. Anaesthesia 1998; 62 (11): 1139-42.

〔連絡先：干204-8575 東京都清瀬市梅園 1-2-1 国立看護大学校研究課程部 武田由美 E-mail: takeday@d15.ncn.ac.jp] 


\title{
Cost Minimization Analysis of Clinically-Indicated Replacement in Peripheral Venous Catheter Management
}

\author{
Yumi TAKedA ${ }^{1,2)}$, Mayumi AminakA ${ }^{1)}$, Haruyo SAKAKI ${ }^{2)}$, Tetsuya FukUdA ${ }^{3)}$, \\ Nao Komagata ${ }^{2)}$, Retsu Fujita ${ }^{4)}$, Namiko Mori ${ }^{1)}$ and Midori NishioKA ${ }^{1)}$ \\ ${ }^{1)}$ Graduate School of Nursing, National College of Nursing, Japan, \\ ${ }^{2)}$ Department of Nursing, ${ }^{3)}$ Department of Pharmacy, Nishisaitama-cyuo National Hospital, \\ 4) The University Tokyo Hospital, Clinical Research Support Center (CresCent)
}

\begin{abstract}
The Centers for Disease Control and Prevention guidelines recommend replacing peripheral venous catheters every $72-96 \mathrm{~h}$ (routine replacement), but studies in recent years have shown that venous catheter replacement is clinically safe to perform only if events occur that make replacement unavoidable, such as phlebitis. This indication is known as the clinically-indicated replacement method. The present historical control study attempted to verify the safety and cost effectiveness of clinically-indicated replacement in a single hospital which had introduced the replacement method. Patient characteristics and event rate were investigated using the peripheral vein catheterrelated surveillance records and medical records. Costs and rates of onset of bloodstream infection, phlebitis, extravasation, and occlusion (events) were compared in the 2 months before and after introduction, excluding the first month after introduction of the clinically-indicated replacement method. The calculated cost included the material cost, personnel expenses, and disposal costs per transfusion treatment. No significant increase was found in the onset of events after the switch from the routine replacement method to the clinically-indicated replacement method. Cost minimization analysis found the increment cost was -268 yen per infusion therapy procedure after the switch from the routine replacement method to the clinically-indicated replacement method.
\end{abstract}

Key words : peripheral venous catheter, cost minimization analysis, phlebitis, bloodstream infection, clinically-indicated replacement 